\title{
The Relation Among Regional Organisations, the Consolidation of Democracy and Citizen Security: The Cases of SICA and UNASUR
}

\section{Octávio Forti Neto*}

\begin{abstract}
Latin American regional organisations (ROs) have been active in the area of citizen security for at least a twenty year-period. An important relationship between citizen security and the democratic consolidation of ROs' official documents in the Latin American region has been unexplored. This leads us to the main question of this paper: 'What has been the role of ROs with a formalized level of citizen security cooperation in the democratic consolidation?' To answer this question, this research was based on two case studies: The Central American Integration System (SICA) and the Union of South American Nations (UNASUR) between 2008 and 2018, the period during which both organizations acted in the area of citizen security. The methodology used in this research was process tracing and comparative process tracing. Its results indicate that organisations developed a vision of how cooperative actions in citizen security can promote the consolidation of democracy by strengthening the rule of law. However, actors are sceptical of the ability of ROs to succeed, given the lack of political interest and the deficit of resources, that are major barriers for them to achieve great success in the citizen security field and, consequently, in the consolidation of democracy. The conclusion is that the analysed ROs produce a lot in terms of documents, but do little in achieving their ambitions, hence constituting, in and of themselves, a reflection of the flaws of the Latin American regionalism.
\end{abstract}

Keywords: cooperation in citizen security; regionalism; democratic consolidation; SICA; UNASUR.

\section{Introduction}

The regional organisations (ROs) in Latin America are numerous. After conducting a brief search, it is possible to find different ROs, such as the South American Common Market, the Andean Nations Community, the Central America Integration System (SICA - acronym in Spanish), the Union of South American Nations (UNASUR), and others. Some of

\footnotetext{
* University Center of Vale do Ribeira (UNIVR), Registro-SP, Brazil; octaviofortineto@gmail.com. ORCID iD
} 0000-0002-4452-838X. 
them link citizen security and democracy development as evidenced in the cases of SICA and UNASUR.

In this sense, this paper will focus on a relevant theme which the ROs have been dealing with for some time: citizen security as a way to consolidate democracy. Therefore, the two main research questions of this paper are: 'What is the vision of the ROs about the relation between democratic consolidation and citizen security in the Latin American region?' and, consequently, 'Is there any role played by the ROs through the democratic consolidation process in Latin America?' This paper delves on two case studies: SICA and UNASUR over a decade's timeframe, namely from 2008 to 2018.

The first hypothesis indicates that the players of both ROs believe that their organisation's focus on citizen security would impact the strengthening of the rule of law, a fundamental basis for the consolidation of democracy. Nonetheless, these players are sceptical with regard to their ROs' accomplishments in pursuing concrete results. Hence, as the second hypothesis, the scepticism occurs due to many factors that hinder significant results in actions concerning citizen security. These many factors involve member countries' domestic responsibilities in allowing the ROs to implement the projects and some institutional shortcomings, common to all Latin American regional organisations.

The paper concludes that the two ROs studied, SICA and UNASUR, were productive in terms of the documents made by them, but they could not operationalise a great part of what they had planned in their workgroups. In this sense, the role of the ROs is not considered effective in actions not only to foment citizen security but also mainly to achieve the consolidation of democracy, strengthening the rule of law.

The methodology employed to analyse these case studies of SICA and UNASUR was process tracing at the first moment and, after that, comparative process tracing. This paper will conduct two kinds of analysis: within the case (Beach and Perdesen 2016) and between cases (Bengtsson and Ruonavaara 2017). In this regard, this work interviewed $31^{1}$ players from SICA, UNASUR and other organisations related to the ROs studied, such as the Organisation of American States (OAS), the European Union (EU) and research institutes.

The comparative argument is that the entire region has problems regarding democratic consolidation and the players of the region make a clear link between these problems and citizen security. Hence, as SICA and UNASUR - covering practically all countries of the region between 2008 to 2018 - deal with this issue as relevant and feasible to this investigation, seeking to understand the impact of the ROs' actions on the processes of democratic consolidation.

Still in the comparative argument, it is important to explain that the criteria that this paper will use to analyse and briefly evaluate the ROs are related to the documents that specify the term security and democratic consolidation, as the first section of this paper will show. In addition to that, the paper will also bring the structures created by the existent projects and the idealized projects, many of which have not come into practice. This will be done in both cases, by splitting them into three key phases: institutional creation, outputs and scepticism. 
In this vein, the paper is divided in three sections: The first will concentrate on the explanation of concepts, focusing on the triad - RO, citizen security and democratic consolidation. The second is based on the presentation of the theoretical-methodological model to be applied in the case studies. In the end, the results from the cases will be presented and some generalisations will be done.

\section{Explanation of the triad: regional organisations, democratic consolidation and citizen security}

\section{Citizen Security, RO and the thematic of democracy}

For the past three decades, the discussion about security has moved beyond its traditional bias and reached other areas (Weiffen and Villa 2017). Tickner (2016) and Goldstein (2016) explain how the concept of non-traditional security has been presented as human security in the literature and by international organisations, especially outside the Latin American (LA) region. Within Latin America, human security has assumed different names, such as democratic, multidimensional and, more recently, citizen security (Tickner and Herz 2012; Muggah and Szabo 2014).

Priers (2017) points out that human security would be the background of all securities mentioned above. Generally, it is understood in a broader concept, related to individuals. This means the focus on the human being as well as on the State as the protector of human life (UNDP 1994). Many authors have sought to distinguish between these security terms (Tavares 2014; Segura and Romero 2013). This paper defines citizen security as '[...] an array of ideas, policies and activities intended to promote safety and security, strengthening social cohesion and reinforcing the mutual rights and obligation of States and citizens' (Muggah and Szabo 2014: 6). The focus is on the strengthening of the rule of law based on the guarantee of observance of human rights.

Goldstein (2016), based on Delgado Aguado and Guardial Maduell's works (1994), conceptualise the term within the context of the defence of basic rights and democracy. Therefore, they elucidate citizen security as:

The protection of the normal functioning of democratic institutions, the defence of the citizenry from criminality in all of its facets and typologies, [and] the defence of citizens against corruption and other asocial acts that impede or problematize the normal development and enjoyment of the fundamental rights of persons (Aguado and Maduell 1994: 20, cited in Goldstein 2016: 141).

Please note that since this definition brings forth an intrinsic relation between non-traditional ${ }^{2}$ security and the strengthening of democratic institutions, especially concerning those which relate to rule of law. In reality, the concepts themselves are still the source of academic debates. Muggah and Szabó (2014), for instance, explain it is easier to operationalise than to conceptualise the citizen security term. Tickner and Herz (2012) 
point out that in the context of transition and post-transition studies, security and democracy have come to have an association, and cooperation or regional integration also came to be seen as '[...] critical instruments of democratization and security' (Tickner 2016: 71).

In that sense, it is important that this paper highlights the regional context of post-transition. Two stages are relevant to describe it, according to Tickner and Herz (2012), the first is democratic security, and the second is the expansion of the term to other areas like transnational threats, which Priers (2017) embraces as citizen security. In this vein, democratic security arises within the context of the end of bipolarism, of re-democratisation of South America and of pacification following the wars in Central America. The relevance of these factors culminated in the revision of national security doctrines in the region, as well as in a conception of regional security in a cooperative manner that generates stability (Tickner and Herz 2012; Tavares 2014). The Contadora Group (1983) - Central America's peace negotiation group - was considered the first effort to bond democracy and security, and eventually the group inserted the thematic of democratisation in the security regional debates (Tickner and Herz 2012).

In the same period, it is important to mention that academic groups started thinking about the formulation of a new concept of security that could be an alternative to the concept of security developed in the context of authoritarian regimes in Latin America. The new concept of security should have as background principles of democracy. The OAS, the South American Peace Commission (1987), the United Nation agencies, and, after that, the ROs, decided that liberal democracy was important to guarantee the security and safety of people (Tickner and Herz 2012; Tickner 2016). In parallel, it is relevant to cite that there were debates between defence and promotion of democracy in different areas (Weiffen and Heine 2015).

From then on, the development of Latin American debates on security exposed other sources of threats named 'new threats' (Muggah and Tobón 2018). The lack of governability in the countries due to insecurity made politicians and experts pay more attention to drug trafficking, common and organised criminality, arms trafficking, violence and, especially the institutional fragilities of the State in the struggle against these new threats (Priers 2017; Goldstein 2016).

In this context, the ROs were comprehended as an important multilateral mechanism to handle the new threats. ROs assume an important role in regional governance (Nolte 2014). The proliferation of ROs conforms a regional architecture that creates an institutional network to bring stability in the region. Bailes and Cottey (2006) point out that the ROs filled the gap between aspects of traditional security and the broader concepts of security, which embrace democracy, human rights and other matters. ROs have a natural role in protecting and promoting good governance. Nolte and Wehner (2012) complement that demonstrating regional governance in security allows the members to solve problems of collective security. According to them, the issue of the institutionalisation in non-traditional security has been the main emphasis of the ROs, second only to the economic aspects of member countries. 
In this vein, Tavares (2014) explains that ROs are seen as more capable to understand, to act and to implement procedures in citizen security, since they are directly connected to their regions. To complement, Goldstein (2016) mentions that many politicians in the Latin American region - as well as domestic organisations, academics and other institutions - have made use of the term citizen security as a common language, focusing on the democratic rule of law. Priers (2017) also explains that policies and programmes have been designed to deal with citizen security as a mechanism of specific governance.

Therefore, there was an understanding in the region regarding drug-related crime, corruption, and fragilities in the rule of law which, among other points, were bringing negative consequences to democratic stability (Nolte and Wehner 2012). This specific vision was that 'diminished violence can be positioned as a function of strengthened democratic process and institutions and vice versa within the idea of growing governance mechanisms' (Priers 2017: 11).

In order to exemplify the argument mentioned above, it is pertinent to introduce the two case studies. Both ROs - SICA and UNASUR - had in their construction process important elements connecting democracy and security. SICA, for example, signed the declaration of Guácimo (SICA 1994) incorporating features of citizen security democracy and rule of law in 1994.

The signature of the Treaty on Democratic Security in Central America, TDSCA, was a notable instrument to amplify the concept of security and bring elements of citizen security to the forefront of the political debate in the region. The TDCSA conceived the terms security and democracy in the same document and was based on guidelines for promoting human rights, the strengthening of civil power and the development of multidimensional security (Peralta 2016).

It is possible to find relevant elements related to security and democracy even in the Tegucigalpa Protocol (SICA 1991). The Protocol points out issues like the strengthening of civil power, the eradication against violence, drug trafficking, and other elements. Hence, the rule of law, fundamentals rights and justice were and are central in the construction of the democratic model in the Central American (CA) region.

Between 1996 and 2001, SICA was concerned about human trafficking and international organised crime (Segura and Romero 2010). Later, from 2001 to 2006, there was an important shift in the way the region understood security due to the fact that drug trafficking and organised crime were targeted by the Colombia Plan in the post-9/11 terrorism agenda, and to the fact that citizen security was linked to the role of the Central American gangs. In the 2006 meeting in Honduras (Bosque of Zambrano), it was argued that the Central American Security Commission (CASC) built a document through presidential declarations proposing some actions to combat the high rates of murder and criminality in the region.

Following Bosque of Zambrano's (2006) declaration, there were many dialogues regarding drug trafficking, transnational organised crime, people and arms trafficking, money laundering and justice assistance (Ramirez 2016). A consensus among the Central American countries that democracy and security were necessary conditions to develop the isthmus sustained therefrom (SICA 1994; SG-SICA 2012). 
In South America, the situation was not different. Two presidential meetings occurred from 2000 to 2002 in the Latin American subregion. The first meeting counted with the initiative of the Brazilian President Fernando Henrique Cardoso to develop an economic, infrastructural and political project in South America. The second related to the construction of peace in the region (Barzaga and Regueiro 2012).

Nery (2016) explained that the first meeting in the year 2000 accounted for the first time the region engaged to discuss important issues to it that related to drug trafficking, economy, security, trade, identity and integration. Among those, the thematic of drugs, violence and democracy were presented. In the 'Comunicado de Brasilia,' issued in the year 2000 (Summit Meeting of the South American Presidents 2000), in Article 26 the term citizen security had already been cited in the context of democratic consolidation within the scope of regional integration.

In the document of the II Meeting of South American Presidents, in 2002 (CLAES 2002), Article 2 incise 'e' expresses the compromise of fighting against the global problem of drug and other crimes. The South American Community of Nations (SACN) had three presidential meetings (2005-2007). CASN's first meeting arose the 'Declaration on Citizen Security in South America' (CASA 2005). The main principle was 'that security is a necessary condition for the freedom exercise [...] in a democratic society. There is no democracy without freedom, and it is impossible for freedom to exist without security' (CASA 2005). The document also contained the 'Program of Action on Citizen Security in South America.'

The idea of advocating for the strengthening of democratic institutions was also present in UNASUR's Constitution Treaty, as Article 3 in the specific objectives from incising ' $q$ ' to ' $u$ ' points out the thematic of citizen security, cooperation in citizen security and democracy (UNASUR 2008). In sum, democracy and non-traditional security are constitutive elements of SICA's and UNASUR's formation. This relation will be shown in the results of this paper.

Table 1 shows the intentional murder rates in Latin American per 100000 inhabitants according to the World Bank from 2000 to 2016. The fact that these numbers were considered in a World Bank index reveals a concern by the member countries that becomes clear by analysing the official documents and interviews conducted by them. In that sense, the regional dialogue on citizen security can be justified by the following table.

In accordance with the indicators on Table 1, it is important to introduce the thematic of cooperation in citizen security. Countries cannot have the capacity to act independently against transnational threats ${ }^{3}$ (CSSCJDOT 2013; CSPMD 2011). There are severe problems in the implementation of the rule of law in most Latin American countries (Dominguez 2013).

The concept of cooperation in citizen security embraces all aspects that relate to the exchange of ideas, assistance and conveyed experiences through an integrated system of governmental and non-governmental institutions, investors, international institutions, associations, local level organisations and ROs (Muggah and Szabo 2014). Within this scope, there are transferences of resources, equipment, intelligence and expertise among 
the members involved in the cooperation. The network is wide and involves defence, police forces, intelligence units, penal and judicial systems, universities, civil associations, companies, and other players (Muggah and Szabo 2014; Muggah and Tobón 2018).

Table 1 - Index of intentional homicides per 100000 inhabitants

\begin{tabular}{lccccccccc}
\hline & $\mathbf{2 0 0 0}$ & $\mathbf{2 0 0 9}$ & $\mathbf{2 0 1 0}$ & $\mathbf{2 0 1 1}$ & $\mathbf{2 0 1 2}$ & $\mathbf{2 0 1 3}$ & $\mathbf{2 0 1 4}$ & $\mathbf{2 0 1 5}$ & $\mathbf{2 0 1 6}$ \\
\hline Argentina &.. &.. &.. &.. &.. &.. & 7.5 & 6.5 & 5.9 \\
\hline Belize & 16.6 & 30.9 & 40.1 & 37.7 & 43.1 & 28.8 & 35.0 & 33.1 & 37.6 \\
\hline Bolivia &.. & 8.4 & 12.8 & 12.3 & 11.9 & 9.0 & 8.9 & 6.3 & 6.3 \\
\hline Brazil & 23.7 & 22.8 & 22.0 & 24.2 & 26.5 & 26.8 & 28.0 & 28.4 & 29.5 \\
\hline Chile &.. & 3.7 & 3.2 & 3.7 & 2.5 & 3.2 & 3.6 & 3.0 & 3.5 \\
\hline Colombia & 65.7 & 34.8 & 33.7 & 34.8 & 35.1 & 32.6 & 27.9 & 26.5 & 25.5 \\
\hline Costa Rica & 6.3 & 11.7 & 11.6 & 10.3 & 8.7 & 8.7 & 10.0 & 11.6 & 11.9 \\
\hline Dominican Republic & 14.1 & 24.3 & 25.0 & 25.1 & 22.3 & 19.2 & 17.4 &.. & 15.2 \\
\hline Ecuador & 14.5 & 17.9 & 17.6 & 15.4 & 12.5 & 11.0 & 8.2 & 6.5 & 5.9 \\
\hline El Salvador & 60.5 & 71.4 & 64.7 & 70.6 & 41.7 & 40.2 & 62.4 & 105.4 & 82.8 \\
\hline Guatemala & 24.9 & 45.4 & 40.7 & 38.0 & 33.8 & 33.7 & 31.4 & 29.4 & 27.3 \\
\hline Honduras & 48.7 & 65.7 & 76.1 & 85.1 & 84.3 & 74.3 & 66.9 & 57.5 & 56.5 \\
\hline Nicaragua & 9.5 & 14.2 & 13.7 & 12.7 & 11.5 & 10.0 & 8.7 & 8.6 & 7.4 \\
\hline Panamá & 9.9 & 15.7 & 12.6 & 14.8 & 16.9 & 17.3 & 14.5 & 11.3 & 9.7 \\
\hline Paraguay & 18.8 & 13.4 & 11.9 & 10.4 & 10.2 & 9.3 & 8.8 & 9.3 &.. \\
\hline Peru &.. &.. &.. & 5.4 & 6.5 & 6.6 & 6.7 & 7.2 & 7.7 \\
\hline Uruguay & 6.4 & 6.7 & 6.1 & 5.9 & 7.9 & 7.6 & 7.8 & 8.5 & 7.7 \\
\hline Venezuela & 32.8 & 48.9 & 45.1 & 47.8 & 53.8 &.. & 61.9 &.. & 56.3 \\
\hline Guiana & 10.1 & 15.7 & 18.8 & 17.4 & 18.5 & 20.4 & 19.5 & 19.4 & 18.4 \\
\hline Suriname & 14.4 &.. &.. &.. &.. &.. &.. &.. &.. \\
\hline
\end{tabular}

Source: The World Bank (2019).

Consolidation of democracy and the Rule of Law: binding with cooperation in citizen security

After the third wave of democratisation in Latin America, research about democracy has been concentrated on three distinguished ways: the 'transitologists', the 'consolidologists' (for example, Linz and Stephan (2001); Diamond (1999); and others), and studies focused on the quality of democratic institutions and its deepening (Morlino 2015).

To avoid a common trap, this paper will not frame the term consolidation of democracy in a unique definition, due to the fact that it is a nebulous and polysemic concept 
(Pridham 1997; O’Donnell 2001). Thus, this paper understands democratic consolidation in terms of a process (Schedler 2001).

Schedler (2001) points out that each author will have his or her objective and context of research when he or she observes a conjuncture. This must be considered when applying one concept or another of consolidation of democracy in Latin America. In that sense, the author understands that the term can embrace a variety of meanings that are systemized in five notions: impediment of democratic rupture; impediment of democratic erosion; institutionalisation of democracy; concretion of democracy, and democratic deepening. In all the categories presented by the author, a democracy only consolidates when there is safety, justice, and other aspects contained in the constitutional law as a base that ensures the order.

According to Morlino (2015), a quality democracy goes beyond the rule of law, since it relates to the functioning and effective respect of the law, taking into account freedom, equality and accountability, which constitute additional characteristics of democracy. Also, according to the author, a quality democracy involves eight notions: rule of law; electoral accountability; inter-institutional participation; competition; freedom; equality, and responsiveness (Morlino 2015). According to the same author:

The rule of law is not only the enforcement of legal norms. It basically connotes the principle of the supremacy of law, that is the Ciceronian legum servi sumus, and entails, at least, the capacity, even if limited, of authorities to enforce the law, and to have laws that are non-retroactive and in public knowledge universal, stable, predictable and unambiguous (Morlino 2015: 181).

This paper clarifies that the dimension of the rule of law is elementary for the functioning of the remaining dimensions of democracy. It is through the nation-state that laws and rights, as well as their management and effectiveness, are promoted. (Morlino 2015). However, as the terms 'democracy' and 'rule of law' also lack a unique definition, consequently many conceptions thereof are contested (Merkel 2012). For the purposes of this paper, Morlino's definition (2015), cited above, will be the basis of this analysis. Table 2 below shows that the concept of the rule of law can cover different aspects.

It is also essential to consider the rule of law for democratic governance, since the former is seen as 'a system of government where institutions function according to democratic processes and norms, both internally and in their interaction with other institutions' (OSCE 2010). The rule of law is fundamental for the occurrence of the process of democratic governance, in addition to the respect for the law and the satisfaction of citizens for public outputs.

Thus, regional cooperation in citizen security can be directly related to the strengthening of democracy in its most basic item - namely, the rule of law. In other words, cooperation in citizen security can improve the rule-of-law mechanism, generating better democratic governance and, consequently, contributing to the consolidation of democracy. The relation between the concepts mentioned is presented in the theoretical model in Figure 1. 
Table 2 - Items aggregated to the dimension of the rule of law

Individual security and civil order focusing on the right to life, absence of fear and torture, personal security and the right to private property guaranteed and protected throughout the national territory;

The erga omnes application of the legal system, also at the supranational level, guaranteeing the rights and equality of citizens;

The absence, even at the local level, of areas dominated by organized crime;

The existence of a local, centralized and civil bureaucracy that competently and efficiently enforces the law and takes responsibility in the event of error;

The existence of an efficient police force that respects the rights and freedoms guaranteed by law;

Equal and unimpeded access by citizens to the justice system in cases of proceedings between private citizens and public institutions;

Reasonably prompt resolution of criminal investigations and administrative and civil court proceedings;

The complete independence of the judiciary from any political influence;

The absence of corruption in the political, administrative and judicial powers.

Source: Created by the author, based on Morlino (2015: 182)

Figure 1 - The impact of ROs on cooperation in citizen security in the consolidation of democracy

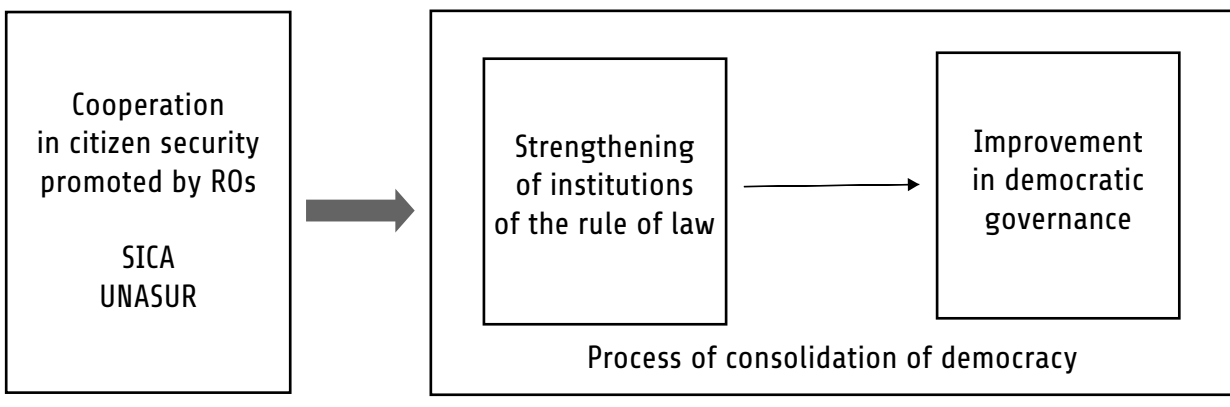

Quadrant 1

Quadrant 2

Source: Forti Neto (2019: 22).

The model of Figure 1 was designed from the definitions presented above, as well as from the different documents and interviews analysed in this work. However, as it will be demonstrated in the empirical section, few actions went from quadrant 1 to quadrant 2. In general, the results will show that ROs perpetrated activities such as exchange of experiences, regional diagnosis, regional seminaries, capacitation, joint actions in tackling arms and drugs trade, development of indicators, and other actions. To complement this paper in the analysis of Figure 1, it is important to bring to the discussion a methodology that helps in the comprehension of the RO's councils and commissions: process tracing. 


\section{Case study, process tracing (PT) and comparative process tracing}

A case study is an important strategy of research focused on the in-depth investigation 'of one, or a small number, of phenomena to explore the configuration of each case [...] and evaluating theoretical explanations' (Ragin 2000: 64, cited in Venesson 2008: 226). Therefore, the case studies are useful to test theories and to explain causal mechanisms.

Allied to case studies, the method of process tracing is fundamental to scientific research. Process Tracing (PT) is a method that helps track a process, looking for a link between a cause (or a conjunction of causes) and an outcome (Beach and Pedersen 2016). PT is relevant for it allows better analytic rigour in qualitative researches. The method brings reliability since there is a control on the observations and a thorough analysis for pieces of evidence (Lima 2017).

Bengtsson and Ruonavaara (2017) define PT as any research that is focused on the monitoring process. The narratives are important in this approach. According to the authors:

We are interested in describing and analyzing the sequence of actions and events that constitutes the process leading to a certain end state without transforming it into variables and values. Such an approach is theoretical not by testing theories but by constructing the narrative in terms and questions suggested by theory (Bengtsson and Ruonavaara 2017: 61).

This paper will analyse two cases: firstly, the Central America Integration System (SICA), through the Central America Security Commission (CASC) and the Central America Security Strategy (CASS), and secondly, the Union of South American Nations (UNASUR), through the South American Council on the drug world problem (SACDWP) and the South American Council on Citizen Security, Justice and Actions Against Transnational Organised Delinquency (SACCSJATOD). The referred cases will entail the analysis of documents of both cases, accounting for acts, action plans, joint reports, minutes, as well as semi-structured interviews composed of open questions that were posed to the different players involved in the process.

The choice for the two ROs is justified by the fact that SICA and UNASUR embraced almost all Latin American countries as member states between 2008 and 2018. Moreover, these RO's integration processes have institutionalised cooperation among countries on citizen security as observed in their councils and their respective meetings, including their action plans, projects, budgets, and the diverse additional players involved.

The time frame of this study is justified by the renovation of Central American Integration, which places the axis of democratic security as a pillar of integration, as well as by the development and implementation of the CASS programme. In South America, from the point of view of the UNASUR, this period embraces the creation of two councils devoted to citizen security and illicit drugs. Falletti (2006: 6) explains that in linking the start and the end of the sequence, the researcher who applies the TGPT [process tracing] 
method has to reconstruct an explicit chronology of the sequence of events that constitute the process of interest.'

In this vein, the source of data in this case will be the documents produced by the councils and the ROs' institutional partners. In the beginning, 101 documents, including minutes and reports from all meetings of the councils between 2008 to 2018, were analysed, of which 27 were from UNASUR's Drug Council, 36 from UNASUR's Citizen Security Council, and 38 from SICA's Security Commission. After that, other documents were collected and analysed: 41 publications, among which are reports and specific results of evaluations and monitoring of the CASS's projects. The same applied to UNASUR - that is, contacts with governments, work documents, reports and informs were considered. In a later moment, the analysis entailed 31 interviews schematised with open semi-structured questions asked to governmental officials, non-governmental workers and other international and national institutions from all Latin American countries.

As validation criteria and research reliability, this paper triangulated the analysed documents from the councils, the information about the results of the projects from relevant sources, the interviews conducted in 2018 and 2019, and the theoretical framework of this research. The aim was to understand the mechanisms involved in the relationship between the ROs with the issues of citizens security cooperation and the consolidation of democracy. Despite the differences between both regions (Central and South), there are many similarities between both processes, as revealed by the comparison between the cases, focused on citizen security and democratic consolidation.

The operationalisation of this study is in Table 3. According to the table, in the relation between $\mathrm{X}$ to $\mathrm{Y}, \mathrm{X}$ is a sufficient condition and $\mathrm{Y}$ is the outcome. Beach and Perdesen (2016) point out that in the PT, there are three variants: theory testing, theory-building and outcome explaining. The focus of this paper will be on the explained outcome, since it seeks to explain results carrying historical aspects based on case studies. As part of the explanation of results, the role of the narratives (Bengtsson and Ruonavaara 2017) is fundamental to each case.

Note that the 'X' accounts for the ROs (SICA and UNASUR) represented by their respective councils. The phase 1 of Table 3 refers to the convergences in a context in which there was an increase of violence, a common threat to the rule of law, hence representing a shared common understanding by the countries to advance in terms of the regional institutions. It is important to emphasize that the convergence mentioned above among all South American countries was facilitated in UNASUR due to the common leftist ideology of the government elected in that period (Nery 2016). In Central America, the convergence was enabled through the support from the European Union and the possibility of a bi-regional negotiation with this bloc (Forti Neto 2019). Phase 1 was marked though many meetings and negotiations in both cases. 
Table 3 - Scheme of the development of process tracing in each case

\begin{tabular}{|c|c|c|c|c|}
\hline Effect (X) & $F_{1}$ & $F_{2}$ & $F_{3}$ & outcome $Y$ \\
\hline \multirow[t]{2}{*}{$\begin{array}{l}\text { Directions of R0s in } \\
\text { developing actions } \\
\text { in cooperation in } \\
\text { citizen security for } \\
\text { SICA and UNASUR }\end{array}$} & $\begin{array}{l}\frac{\text { Phase of }}{\text { institutionalisation }} \\
\frac{2008-2010}{\text { Regional }} \\
\text { alignments of the } \\
\text { ROs } \\
\text { SICA } \\
\text { UNASUR }\end{array}$ & $\begin{array}{l}\text { Phase of outputs } \\
\text { 2010-2016 } \\
\text { Implementation } \\
\text { and results of the } \\
\text { RO's actions }\end{array}$ & $\begin{array}{l}\text { Phase of scepticism } \\
\frac{2016-2018}{\text { Ineffective results }} \\
\text { at the macro } \\
\text { level for SICA and } \\
\text { UNASUR }\end{array}$ & $\begin{array}{l}\text { A sceptical vision } \\
\text { of the players } \\
\text { about their ROs } \\
\text { promoting DC. } \\
\text { Limitation of ROs } \\
\text { in promoting DC } \\
\text { though CS }\end{array}$ \\
\hline & $\begin{array}{l}\text { Players: } \\
\text { High RO ranking - } \\
\text { States } \\
\text { Narratives }\end{array}$ & $\begin{array}{l}\text { Players: } \\
\text { Officials, experts, } \\
\text { other ROs - } \\
\text { national/ regional } \\
\text { level } \\
\text { Narratives }\end{array}$ & $\begin{array}{l}\text { Players: } \\
\text { Officials, experts } \\
\text { and other ROs } \\
\text { Narratives }\end{array}$ & $\begin{array}{l}\text { ROs have a low } \\
\text { impact on actions } \\
\text { to strengthen the } \\
\text { rule of law and } \\
\text { thus on DC }\end{array}$ \\
\hline
\end{tabular}

Phase 2 outputs were characterised by the construction, development and implementation of projects. This phase was characterised by an intense production of documents and methods to implement the activities planned. After the evaluation of results from phase 2 between 2015 and 2016, the phase of scepticism, F3, was revealed. That is, there is a common understanding that the ROs are uncapable of strengthening the rule of law for many reasons and, consequently, the idea of consolidation of democracy failed to be observed.

\section{Results: SICA and UNASUR}

This paper analysed two ROs, as pointed out in table 3. Both ROs had a similar way in treating the problem of citizen security, doing so by binding it to the thematic of the consolidation of democracy and the rule of law in their official documents. These will be described in the following section.

\section{Central America Integration System (SICA)}

Phase of institutional creation (2008-2010)

It is important to acknowledge that SICA had already promoted some initiatives regarding democratic security before 2008. The Treaty on Democratic Security in Central America (TDSCA) (SICA 1995) gathered three fundamental aspects of the 1980s and 1990s in Central America: regionalism, democracy and security. However, despite the fact that the region produced many documents in the area of security including the Central American Security Commission (CASC) between 1995 and 2007 (Segura and Romero 2010), there was a clear stagnation of the regional integration process (Pozo 2016). Moreover, the magnitude of the projects designed from CASS was never seen before 2008. 
In that sense, the phase 2008-2010 was based on two fundamental features: the political will to foment a reform of the system, and the desire of actors in giving some sense to the process of integration to the societies of the SICA member states (Pozo 2016; Peralta 2016; Carrillo 2016). From this period on, the democratic security unit and the CASS arose. Furthermore, the negotiation of the main points of the CASS was conducted in the same period and included the creation of a friend group to finance many projects (Ramirez 2016).

There was also the intention to create a regional public security policy tied to CASS. The players, aware of the bold character of the initiative, searched for international cooperation to develop 22 project profiles (ESCA 2011). The creation of the ESCA was crucial as a political focal point ${ }^{4}$ in the region, as it activated a planned action in citizen security as a means to solve collective problems such as organised crime, drug trafficking, gangs, violence, weaknesses of justice institutions, prison crises, and other problems common to Central American countries.

Referring to Democracy, the treaties, the discourses and other documents highlight the role of regionalism as an important means to consolidate democracy, as exposed in the first section of this paper. The main specific objective of the Tegucigalpa Protocol (SICA 1991) is to consolidate the democracy, as well as the TDSCA (SICA 1995), whose central objective is pointed as strengthening the rule of law. Moreover, CASS's principles articulate its main objective as promoting the rule of law as a means of strengthening democracy. Two high ranking officials from Guatemala and El Salvador point out that the CASS is, in fact, a continuation of the TDSCA (Senior Official of the Ministry of Foreign Affairs of Guatemala, interview by author, 18 February 2019; Official of the Ministry of Foreign Affairs of El Salvador, interview by author, 7 June 2018).

Furthermore, the discussion about SICA's institutional modernisation consisted of experts of integration as consultants (Carrillo 2014). The development of ESCA and the advance in the customs union were essential to give some response to the existence of the SICA to Central American society (Carrillo 2014).

\section{Phase of outputs}

The following years (2010-2016) were years of implementation and management of the CASS projects, as well as the evaluation of parts of the regional strategy for security in Central America. In pursuing the CASS, an observatory was created for the development of statistics (OBSICA), resources were demanded to the CASC, and the CASS had international recognition as public policies (Carrillo 2016). The resources concentrated on the regional sphere demanded more attention to the CASC, because this institution distributed the resources to external financing (Senior Official from Central American Court of Justice, interview by author, 22 May 2018) to fund the chosen approved projects.

Altogether, the CASS represents 22 profiles of projects in four-axis: crime combat, violence prevention, rehabilitation, reinsertion and prison security, and institutional strengthening. The resources are overwhelmingly from international cooperation mechanisms, namely from the European Union, Spain and the United States as its main donors. 
In the beginning, the CASS previewed a budget of 2.103b US dollars (403 million from the donation and 1.7 billion from loans) (Ramirez 2016). In practice, the budget did not achieve the amount forecasted, achieving only 79m euros (SG-SICA 2012).

After six years, most projects were evaluated and many of them did not achieve the goals that had been planned for them. The countries had not reached concrete results and the initiatives had gradually lost the number of resources, especially due to the way the projects had been managed and the inconstant relationship among the Central American countries and the SICA. Consequently, the bilateral relations took on more space, mainly due to the possibility to control and reach concrete results, which was confirmed by CSC documents and interviews conducted. To exemplify this, the SG-SICA (2017) exposed that in the year of 2017, the CASS budget was just $2.5 \%$ than the value that had been prearranged to arrive through international cooperation in 2011. Table 4 shows the ESCA projects from the System of Information of Regional Cooperation (SICOR).

Table 4 -SICOR Projects

\begin{tabular}{lcccc}
\hline Code/ name & $\begin{array}{c}\text { Start date of } \\
\text { execution }\end{array}$ & Financial source & $\begin{array}{c}\text { Total amount } \\
\text { (million dollars) }\end{array}$ & Current status \\
\hline SEFRO & $10 / 01 / 2010$ & EU & 8.520 .000 & In execution \\
\hline CASAC & $11 / 21 / 2012$ & EU & 2.967 .000 & In execution \\
\hline A.B.1 & $04 / 01 / 2013$ & Canada & $579.396,10$ & $\begin{array}{c}\text { Finalised } \\
\text { (03/31/2015) }\end{array}$ \\
\hline B.A.1 & $07 / 01 / 2013$ & $\begin{array}{c}\text { Finland and } \\
\text { Netherlands }\end{array}$ & 18.593 .852 & In execution \\
\hline B.E.1 & $12 / 01 / 2013$ & EU & 7.427 .959 & In execution \\
\hline D.B.1 & $07 / 02 / 2012$ & Spain & $7.044 .109,20$ & In execution \\
\hline D.B.1 & $12 / 13 / 2013$ & EU & $21.724 .345,50$ & Approved for \\
execution
\end{tabular}

Source: Created by the author, based on SICOR (2018). Also available on Forti Neto (2019: 140-141).

Despite the information in the table above, some outputs in the regional, national and local spheres should be mentioned, especially due to the role of international cooperation, represented overwhelmingly by EU and Spain. Out of 22 profiles of projects, only 10 had some degree of implementation. In a way, the actions of ESCA (Table 4) can be considered as multi-level. At the same time, some deficiencies were found, as will be shown below. 
The phase of scepticism is characterized by the emptying of the importance of the CASC and the decreasing of resources allocated to the CASS projects. It is possible to point out some domestic electoral crises in some member states. Although the rhetoric of players shows actions in democratic security in the region are important, the SICA did not produce the satisfactory outputs to cause real changes in Central America, meaning that the CASS projects were regarded as ineffective in the opinion of most actors interviewed.

It is possible to notice that there is indeed an abysm between the importance that actors place on the documents and the capacity that they have to realise something as practical and lasting in the region. In the case of SICA, there is the idea that the relationship between democracy and security is fomented on the strengthening of the rule of law. However, CASS specifically is not considered a key instrument to the consolidation of democracy in Central America.

In general, the actors interviewed disqualify SICA/CASS for many reasons. The most important of these reasons is the fact that the ROs did not reflect the reality of Central American countries. In this sense, for many respondents, there is a gap between regional and national actions, especially due to the lack of knowledge of local realities. An official from OBSICA, for example, explained: 'I believe that, for now, political decisions regarding security in the region suffer from good information and are taken without evidence' (Official from SICA Observatory, interview by author, 2018). The same official adds that there is a lack of monitoring and evaluation mechanisms to provide reliable information in terms of orienting the decision-making in democratic security.

Similarly, there is lack of connection - information and joint action - between the national and regional institutions in strengthening the rule of law, as exposed the in Programme 'Estado de la Nación. Even though horizontal cooperation among policies is observed, 'they do not communicate, people do not know, besides this, the cooperation is a secondary element in the security police of each country.' The respondents from the 'Estado de la Nación' explained that the bilateral cooperation with the USA was prioritized rather than the cooperation with SICA (Neto 2019).

Other reasons that disqualify the CASS include the lack of effective institutions, more specifically, '[...] the chronic institutional debility of the great part of the States [...] especially that related to the system of judicial administration' (Representatives of the Programa Estado de la Nación, interview by author, 17 May 2018). Moreover, Central American countries are not habituated to cooperation (Representatives of the Programa Estado de la Nación, interview by author, 17 May 2018): the non-existence of a 'culture to generate politics or joint actions [...], the lack of political will to give impulse to projects and integration, the lack of accountability (Official from the Organization of American States in Honduras, interview by author, 6 August 2018) and corruption of public agents are found in the actors' narratives.

There are some optimistic players. Some, as the official from El Salvador, elucidated that the strategy is following its course and that the problem lies in the complexity of the violence in the region (Official of the Ministry of Foreign Affairs of El Salvador, interview 
by author, 7 June 2018). Furthermore, other players explained that the CASS helps to harmonise the region concerning a common problem, namely stability and cooperation in security (Former Researcher from Instituto de Estudos Estratégicos e Políticas Públicas of Nicarágua, interview by the author, 4 June 2018). Another official from Guatemala stated that the region was better than it was 15 years ago, to which the SICA/CASS contributed fundamentally (Senior Official of the Ministry of Foreign Affairs of Guatemala, interview by the author, 2018).

The conclusion is that factors such as the lack of human and financial resources, of political will in bringing changes, of accountability of the projects, State corruption and the fact that institutions are getting more political than technical render the SICA ineffective in cooperation in citizen security and, consequently, in the consolidation of democracy, generating scepticism among the actors.

\section{Union of South American Nations (UNASUR)}

The UNASUR arose from a context in which the countries demanded a sense of South American identity. It is important to cite that the UNASUR was meant to avoid the presence of the United States in the region in a strategic manner (Mellado 2013). In that sense, an integration project was designed not only for economic and infrastructural purposes, promoted by leftist presidents elected from 2002 to 2007, but also with political and cultural aims (Ruvalcaba and Valencia 2012). Citizen security and drugs were included in the agenda.

\section{Phase of institutional creation (2008-2010)}

Before the creation of the councils, clues indicated that the region converged to a citizen security cooperation area focusing on democratic consolidation, as exposed at the beginning of this paper. The main perception was that the increase of violence, criminality, inefficient justice, prison overcrowding, and other problems would deteriorate the democratic institutions.

Therefore, with the constitution of UNASUR, sectorial councils were created from 2008 on, one of which was the council of combat against drug trafficking, as part of the South American Defence Council. In 2010, it changed to the South American Council against the World Drug Problem (SACDWP) - a clear response to the Colombian intention to align with the United States (Foglia 2017). The creation of the Citizen Security Council (2012) was another relevant institution institutionalised to tackle the violence and injustice in the region.

This phase was considered an institutional creation phase because of the advances in citizen security and due to the institutionalization of UNASUR and its councils. The documents mentioned above, in first section of this paper, and the Constitutive Treaty (UNASUR 2008), show the convergence between the theme of citizen security and of democracy in the region. 
Phase of outputs (2010-2016)

In the following years, action plans were developed in both councils that related to citizen security cooperation, namely SACDWP and SACCSJATOD. The action plans assumed a great number of goals to be achieved in five years, since the regional problems were latent in the region. For example, SACCSJATOD alone assumed 138 goals in an action plan between 2013-2017. The same occurred with SACDWP, with seven workgroups between 2010 and 2015. Tables 5 and 6 show the SACDWP and SACCSJATOD workgroups.

Table 5 - SACDWP Workgroups (2010-2015)

\begin{tabular}{l}
\hline Workgroups \\
\hline 1- Demand reduction; \\
\hline 2- Alternative, integral and sustainable development, including preventive; \\
\hline 3- Supply reduction; \\
\hline 4- Control measures; \\
\hline 5- Money laundering; \\
\hline 6- Institutional strengthening and legislative harmonization. \\
Source: Created by the author, based on Forti Neto (2019: 200).
\end{tabular}

In a similar period, SACCSJATOD's action plan was designed, as shown in Table 6.

Table 6 - Thematic axis of the Citizen Security Council (SACCSJATOD)

\begin{tabular}{ll}
\hline Axis & \multicolumn{1}{c}{ Alignments } \\
\hline Citizen Security & $\begin{array}{l}\text { Strengthening institutional capacities and policy strategies in citizen security } \\
\text { Strengthening citizen participation } \\
\text { Citizen security with a human rights perspective } \\
\\
\text { Management of citizen security of population in border areas }\end{array}$ \\
\hline Justice & $\begin{array}{l}\text { Strengthening of judicial systems } \\
\text { Strengthening access to justice }\end{array}$ \\
& Formulation and implementation of justice policy with a human rights perspective \\
& Strengthening prison policies and social rehabilitation \\
\hline Transnational & Strengthening policies to address T.0.D. \\
Organized & Cross-border cooperation \\
Delinquency & Cooperation against T.O.D. \\
(T.O.D.) & Institutional capacity building for the fight against T.O.D. \\
\hline & \multicolumn{1}{c}{ Source: Forti Neto (2019: 202) }
\end{tabular}

The methodology applied to the meetings to list the actions according to the subjects of interest of the countries shows that some members have more responsibility than others (SACDWP 2011; SACCSJATOD 2013). Moreover, the reports show some actions delayed and constant mismatches in some meetings, leading to a defective diagnosis and even to the lack of consensus in another workgroup. This indication was also confirmed in conducted interviews. 
There has been the development of a second stage at the SACDWP. The SACDWP presented ineffective results following the workgroups evaluation. The second stage brought a more realistic and suitable amount of actions, pointing to the fact that the workgroups required consensus. Notably, the UNASUR was suffering from a complex ideological difference in many issues. The following Tables 7 and 8 show the negotiation results, according to official documents from SACDWP and SACCSJATOD and Neto (2019).

Table 7 - Synthesis of actions achieved through SACDWP

\begin{tabular}{|c|c|c|}
\hline Workgroups & Priority axes & Goals from 1 to $5^{*}$ \\
\hline Demand reduction & $\begin{array}{l}\text { Physical and virtual diffusion and working meetings with } \\
\text { academics, experts and citizens. Information exchange } \\
\text { and administrative management experience on demand } \\
\text { reduction. }\end{array}$ & 3 \\
\hline $\begin{array}{l}\text { Alternative, integral and } \\
\text { sustainable }\end{array}$ & $\begin{array}{l}\text { Exchange of experiences, information and best practices } \\
\text { on the subject. }\end{array}$ & 3 \\
\hline $\begin{array}{l}\text { Alternative, integral and } \\
\text { sustainable development, } \\
\text { including preventive } \\
\text { development }\end{array}$ & $\begin{array}{l}\text { Implementation of information exchange mechanisms } \\
\text { among producers of programs in the area. }\end{array}$ & 3 \\
\hline Supply reduction & Priority axes without data. & -- \\
\hline Control measures & $\begin{array}{l}\text { Information exchange and intelligence activities against } \\
\text { criminal groups operating transnationally. }\end{array}$ & 3 \\
\hline \multirow{2}{*}{ Money laundering } & $\begin{array}{l}\text { Exchange of experience between financial intelligence } \\
\text { units. }\end{array}$ & 2 \\
\hline & $\begin{array}{l}\text { Contribute to regional strengthening for judicial } \\
\text { assistance systems (detention, confiscation, etc.). }\end{array}$ & 2 \\
\hline \multirow{2}{*}{$\begin{array}{l}\text { Institutional } \\
\text { strengthening and } \\
\text { legislative harmonization }\end{array}$} & Promote and strengthen national drug observatories. & 4 \\
\hline & $\begin{array}{l}\text { Develop commonalities among drug observatories in } \\
\text { order to create a network. }\end{array}$ & 5 \\
\hline
\end{tabular}

*Evaluation of the axes: 1- minimum achieved e 5- maximum achieved.

Source: Created by the author, based on Forti Neto (2019).

Table 8 - Summary of completed, initiated and uninitiated actions from the SACCSJATOD (2013-2017)

\begin{tabular}{lccc}
\hline Thematic axis & Completed & Initiated & Uninitiated \\
\hline Citizen Security & $34 \%$ & $11 \%$ & $55 \%$ \\
\hline Justice & $25 \%$ & $16 \%$ & $58 \%$ \\
\hline Transnational Organised Delinquency & $45 \%$ & $7 \%$ & $48 \%$ \\
\hline Mean & $34.6 \%$ & $11.3 \%$ & $53.6 \%$ \\
\hline
\end{tabular}

Source: Forti Neto (2019: 209). 
Phase of scepticism (2016-2018)

After the phase of low projects results, the councils of UNASUR turned into the scepticism phase. It is important to cite that this analysis - carried out until 2018 - entails a period in which the RO in question was still functional. The consensus is that the documents, as well as the interviews, were a relevant room for discussions about the thematic of citizen security between 2008 to 2018 .

In that sense, the region had some kind of cooperation in citizen security which, in the vision of many interviewers, was attached to the consolidation of democracy - especially in the strengthening of rule of law institutions. For many respondents, the consolidation of democracy would be an indirect but natural effect when the institutions focus on citizen security and drug issues. ${ }^{5}$

An official from Peru said that drugs in Latin America have created the 'narcopoliti$c a$ ' (drug trafficking politics), which in some countries is directly represented in national congress, in cases it is involved in corruption schemes and it deteriorates the rule of law institutions (Senior Official from Peru, interview by the author, 2018). Other players who were interviewed pointed out that the insecurity can decrease the institutions of the rule of law. A national project coordinator of the SACCSJATOD from Peru expressed the low confidence in judicial institutions, police, and in general, in the state or government entities, as determining hints of the quality of democratic consolidation processes' (Senior Official from the Ministry of Justice and Human Rights of Peru, interview by the author, 30 October 2018).

In general, the respondents were emphatic in presenting that the main problem of the UNASUR resided in the ideology that truncated the discussions at the councils. Such an overwhelmingly political character hindered the technical and scientific aspects of the debate, according to many interviewees. ${ }^{6}$ Furthermore, the lack of resources was cited a few times, although it was already clear in the documents. Another common problem was the empty institutions, especially the minor active role of the general secretariat in fostering the development of UNASUR's actions. ${ }^{7}$ Additional difficulties pointed out were the staff turnover, different domestic visions about the issues in question, and the lack of responsibility in the accomplishment of the deadline.

\section{Implications of the cases and their similarities}

Three key points will be analysed within the lack of effectivity in the actions of security in democratic consolidation. The points refer directly to the proposed model at the beginning of this paper, according to Figure 1. Both SICA and UNASUR present similar characteristics in terms of citizen security and of the consolidation of democracy. All points considered have direct implications for the modus operandi of Latin American regionalism, such as the intergovernmental process, different levels of instability, the gap between objectives, and results in both the medium and the long term. 


\section{Intergovernmental process}

Latin American regionalism poses sovereignty as a non-negotiable factor in the relation among the countries. Therefore, the role of any RO in the region will have to follow this logic. The same is observed in both cases studied. Although SICA has some space to be supranational, the RO has made very little progress to achieve this in recent years. The decisions made reside on the hands of the presidents based on integration institutions such as CASC (CSC 2006). The UNASUR did not have supranational aspirations. The decision from the councils was based on the need for consensus predicted on the statutes.

Sovereignty is a sensitive issue in the opinion of most of the interviewees, as well as in the analysis of the treaties. The understanding that only the political will linked to an elected politician will foment or follow the agreements made within the ROs is common. According to this point of view, the ROs do what the countries allow them to do. In other words, within the intergovernmental characteristics of the Latin American regionalism, it is evident that the $\mathrm{RO}$ is allowed a very limited role to play in the case studies that refer to the action of RO in citizen security and democratic consolidation.

In both cases, it is possible to identify that there is no confidence among the member countries, especially in the sharing of sensible information regarding organised crime, border security, import and export of legal drugs, and other aspects. Through the analysis of the documents, it was possible to identify that most of the data was not available because the countries did not have that information to provide to SICA and UNASUR. Many documents rhetorically indicate that Central and South America are united, but both ROs were restrictive about data sharing. In some subjects, the countries did not give the proper attention to progress in the solution of issues. ${ }^{8}$

\section{Instability on different levels}

The crises of different levels are common in Latin American regionalisms (Dabene 2009). Whether domestic crises - as the ones in Venezuela, Nicaragua, Honduras, Colombia - or regional crises - as those between Colombia and Venezuela, or Costa Rica and Nicaragua, there is always a potential regional destabilizing factor that involves ROs in some way. The economic, political, social and security crises generate instability in the region, upsetting the fragile democratic institutions of the member states, especially with regard to the rule of law.

Sometimes, the RO comes into an agreement, but sometimes it does not, as seen in the recent case of UNASUR. Likewise, the SICA had crises like Honduras that even delayed the previewed reforms of 2009. Recently, the CA bloc has been criticised for not having a remarkable position against the Nicaraguan government and the election of Honduras.

The crises of citizen/democratic security in the Latin American countries have been a common point in both cases. Some interviewers pointed out that the lack of SICA's effectiveness to promote the strengthening of the rule of law has played a part in domestic crises in Central America. A researcher from ILANUD indicated that the SICA left 
the countries to solve their rule of law problems independently, which opened space to non- effective yet restrictive policies, such as the 'mano dura' (Iron Hand) in Mexico, El Salvador, Guatemala, and Honduras.

\section{Institutional designs reflect the interests and strategies of their founders}

The construction of UNASUR's councils of citizen security and the development of SICA/ CASS are examples of pragmatic regionalism that turned to collective issues in a certain historical context. Each context was marked by its common traces related to its founder (Nolte 2014). In the case of UNASUR, this was more prominent, since it originated from a leftist group of presidents (Chávez, Kirchner and Lula) who developed the RO. The ideological factor was very important in this case, given that, as the right-wing governments were elected, the RO became conflictive. Another factor about UNASUR that differentiates it from SICA is the role of the USA in each region. While the former did not want the USA acting within it, the latter initially included the United States as a sponsor. The SICA had other priorities in the development of the CASS, such as making a case for integration as a more meaningful aspect for society.

The role that the United States possesses in the region has changed throughout the years. To Central America countries, the North American country always had some bind (Peralta 2016). Peralta (2016) explains that the USA ' [...] is the first trading partner of the region, one of the main investors and providers of cooperation, tourism and, fundamentally, the recipient of the vast majority of Central American emigrants.'

Besides, the United States has worked bilaterally with some countries of that region through the Central American Regional Security Initiative. It is also important to cite the Plan for Alliance of Prosperity for Triangle North, a plan developed to make Honduras, Guatemala and El Salvador more productive by investing in human capital, citizen security and in the strengthening of local institutions. According to Meyer (2019), the USA spent $2.1 \mathrm{~b}$ dollars in the region in 2016.

The SICA lacks homogeneity in the relationship among the member countries (Peralta 2016; Fuentes and Pellandra 2011). There are two sub blocs within SICA. The first is the Central America bloc of the four countries (CA-4) composed of Guatemala, Honduras, El Salvador, and Nicaragua, because its members signed all the treaties and advanced in the free circulation of people and products. The second bloc consists of the states that selectively choose which treaty they want to sign, that entails Costa Rica, Panama, Belize and the Dominican Republic. The reason for the existence of two sub blocs involves historic and cultural features, economic problems and the fear of losing autonomy, as was the case of Costa Rica. There were also some territorial conflicts, as that between Costa Rica and Nicaragua from 2010 to 2015. Although the International Court solved it, there is still some remnant of conflict revolving the issue.

The UNASUR has revealed a conflictive relationship among its members states and likewise with the outside of the bloc. The signature of the bloc as it came up was the creation of a South American regional organization without the presence of the United States 
(Mellado 2013). The OAS also had a diminished role in the region, since the UNASUR became a room for negotiation and discussion among the South American countries (Nery 2016). Nery (2016) states that the United States wanted to hinder the union among the countries of the region, given that if Brazil, Argentina and Chile were aligned, these could have more gains in terms of diplomatic power.

Thus, the UNASUR, and the meeting that originated it, achieved something new in the region: the dialogue among South American presidents. Nery (2016) points out that South America had never signed a document binding that many countries from the region. The focus of the UNASUR was to create a common identity to start the dialogues. It worked until 2018. Before 2018, it was possible to have different economic projects from countries like Brazil and Venezuela, Colombia and Venezuela, and others on the same table. Lehmann e Neto (2016: 6) explain:

[...] there has been a trend towards ideological division, with some countries, such as Colombia or Chile, continuing a policy of, broadly speaking, liberal and free market based policies (whilst opting mainly for bilateral international engagements) whilst others, such as Venezuela or Ecuador, took a decidedly leftwards turn trying to implement what, in Venezuela, has been called the "socialism of the $21^{\text {st }}$ century."

In this vein, the 12 countries within the UNASUR did not have similar perceptions about South America's reality. Some of them had the anti-US imperialism idea, like Ecuador and Venezuela; others, like Colombia, were closely related to the USA (Lima 2013). The UNASUR allowed heterogeneity in economic and ideological aspects. However, it has changed in its last two years with the takeover of right-wing governments and the exit of many of its members. The creation of the Forum for the Progress of South America (PROSUL) was also important to decree the paralysis of UNASUR, given that it is a forum idealized by the right-wing governments, which are more prone to US ideas.

\section{Final considerations}

The first conclusion drawn from this analysis is that the ROs, mainly those in the case studies, have produced different documents to face the problems of citizen security for years. In practical terms, they present very few results, except for punctual actions. As shown in Figure 1, RO's actions go in a limited way from regional to national areas; as such, they produce many documents, yet accomplish very little operationally.

Indeed, there is a common vision, expressed in the interview documents, that the citizen/democratic security contributes to the consolidation of democracy - especially in strengthening of the rule of law. However, most actors interviewed are sceptical about the capacities of their respective RO in terms of having successfully achieved their aim.

What is evident is that there is a deep abyss between the ambitions of actors - reflected in the citizen security regional documents - and the reality to achieve some results at a 
macro level. This paper shows that in both ROs, the logic mentioned above is common. It corroborates to the studies of Dabene (2009) about Latin American regionalism concerning an emptiness of objectives and results. It also confirms that the cooperation in citizen security is observed in both the ROs considered in this paper.

Furthermore, Latin American ROs could not advance from the macro to the micro-level in solving issues of rule of law, as shown in Figure 1. The countries do not let the regional institutions work in their country nor offer clear information to their ROs. They see each other as possible adversaries, and many countries use the rhetoric of integration as a demonstration effect to the international community. In practice, they are not open to implementing the procedures, especially because the decision is not automatically binding in the domestic arena. Although Latin American regionalism is important to bring the thematic of democratic consolidation and an arena of discussion to the table, the style of regionalism is also impeditive to advance in the solution of these same issues.

Therefore, the conclusion about the relation RO, democratic consolidation and citizen security is that ROs in their limited scope of action achieve some possible results, creating a level of dialogue in the region. Sometimes actions go from the regional to the domestic area. When this happens, this contributes to the consolidation of democracy and, consequently, to strengthening the rule of law. For future field research, it would be interesting to analyse the way the decisions made in the RO's regarding citizen security influence the institutional entanglement among their respective member countries.

\section{Notes}

1 The interviews were conducted by e-mail (questionnaires), phone and videoconferences from May 2018 to February 2019.

2 Traditional security relates to the defence of the State and its borders, and to conflict among countries. Non-traditional security involves new threats, such as organized crime, drug trafficking, and general violence (Marcella 2013)

3 This was the view of different respondents, such as officials from Guatemala, El Salvador, Peru, Guiana, SICA and UNASUR.

4 In Process Tracing, the focal point is the moment in which there is a beginning of a process because of some decision taken, and critical junctures are the periods in which the decisions were taken, making it hard to go back (Bengtsson and Ruonavaara 2017).

5 Out of the 11 interviewees - mostly officials related to UNASUR (2018-2019) - only a Brazilian Official did not agree that UNASUR could consolidate democracy through actions in citizen security.

6 Two officials from Uruguay and Colombia were emphatic about this theme (Ambassador of Uruguay, interview by author, 6 October 2018; Ambassador of Colombia, interview by author, 27 November 2018).

7 This was confirmed by an official from UNASUR (General Director of Citizen Security) in a videoconference (Official from UNASUR, interview by author, 30 October 2018).

8 This was a pattern found in the interviews and in the documents from council workgroups. 


\section{References}

Bailes, A J K and A Cottey. 2006. 'Regional security cooperation in the early 21 st century'. In Stockholm International Peace Research Institute (ed), SIPRI Yearbook 2006: Armaments, Disarmament and International Security. Oxford University Press: Oxford, pp. 195-223.

Barzaga, M and L M Regueiro. 2012. UNASUR: proceso y propuesta. Quito: Fedaeps.

Beach, D and R B Pedersen. 2016. Causal case study methods: foundations and guidelines for comparing, matching, and tracing. Ann Arbor: University of Michigan Press.

Bengtsson, B and H Ruonavaara. 2017. 'Comparative Process Tracing: Making Historical Comparison structured and focused.' Philosophy of Social Science 47 (1): 44-66.

Carrillo, F S. 2016. 'Los modos de las políticas de la integración Centroamericana.' Revista de Derecho 20: 31-46.

Comunidade Sul-Americana de Nações (CASA). 2005. Declaración de Seguridad Ciudadana en Sudamérica. Fortaleza. 30 September. At http://www.iri.edu.ar/publicaciones_iri/manual/Listos\%20 para\%20subir\%20III/Integraci\%F3n-Latinoamerica/UNASUR/decl_seguridad_ciudadana_sudamerica_cns_2005.pdf [Accessed on 9 December 2019].

Centro Latino Americano de Ecología Social (CLAES). 2002. Segunda Reunión de Presidentes de América del Sur 2002: Consenso de Guayaquil sobre Integración, seguridad e infraestructura para el desarrollo. Guayaquil, 26-27 July.

Comisión de Seguridad de Centroamerica (CSC). 2006. Reglamento Interno de la Comisión de Seguridad de Centroamérica. 20 October. At https://www.sica.int/documentos/reglamento-interno-de-la-comision-de-seguridad-de-centroamerica_1_26889.html [Accessed on 11 December 2019].

Conselho Sul-Americano sobre o Problema Mundial de Drogas (CSPMD). 2011. Acta de la Reunión del Consejo Suramericano Sobre el Problema Mundial de las Drogas: Plan de Acción del Consejo Suramericano Sobre el Problema Mundial de la Droga. La Paz.

Conselho Sul-Americano em Matéria de Segurança Cidadã, Justiça e Coordenação de Ações em Delinquência Organizada Transnacional (CSSCJDOT). 2013. II Reunión de la Instancia Ejecutiva del CSSCJDOT: Acta. Lima.

Dabène, O. 2009. The Politics of Regional Integration in Latin America: Theoretical and Comparative Explorations. London: Palgrave Macmillan.

Dominguez, R. 2013. 'Challenges to Security Governance in Latin America.' Paper delivered at 7th ECPR General Conference Sciences PO. Bordeaux, France, 4-7 September.

Estrategia de Seguridad de Centroamerica (ESCA). 2011. Proyectos Regionales de la Estrategia de Seguridad de Centroamérica. 11 June. At https://www.sica.int/esca/proyectos.aspx [Accessed on 11 December 2019].

2019. Marco Juridico de la ESCA. 11 December. At https://www.sica.int/esca/marcojuridico

[Accessed on 11 December 2019].

Falleti, T G. 2006. 'Theory-Guided Process-Tracing in Comparative Politics: Something Old, Something New. Newsletter of the Organized Section in Comparative Politics of the American Political Science Association 17 (1): 9-14.

Foglia, M. 2017. 'La participación Argentina en la agenda de cooperación de seguridad y lucha contra la criminalidad organizada de la Unasur.' Revista de Estudios en seguridad internacional 3(1): 61-79. 
Forti Neto, O. 2019. A relação entre Organizações Regionais, consolidação de democracia e segurança cidadã na América Latina: um estudo voltado para o SICA e a UNASUR. PhD Thesis, University of São Paulo, Brazil.

Fuentes, J and A Pellandra. 2011. El Estado Actual de la Integración Centroamericana. México: Relatório CEPAL.

Goldstein, D M. 2016. 'Citizen Security and human security in Latin America.' In D R Mares and A M Kacowicz (eds), Routledge Handbook of Latin American Security. London: Routledge, pp. 138-148. Heine, J and B Weiffen. 2015. 'The challenges of regional democracy promotion.' In J Heine and B Weiffen (eds), 21st Century Democracy Promotion in the Americas: Standing Up for the Polity. New York: Routledge, pp. 10-29.

Lima, M R S. 2013. 'Relações Interamericanas: a nova agenda sul-americana e o Brasil.' Lua Nova 90: 167-201.

Lima, I A. 2017. 'Técnicas Qualitativas em Análises de Causalidade: Aplicações do Process Tracing.' Revista Eletrônica de Ciência Política 8 (1): 128-143.

Marcella, G. 2013. 'The Transformation of Security in Latin America: a Cause for Common Action' Journal of International Affairs 66 (2): 67-82.

Merkel, W. 2012. 'Measuring Rules of Law: virtues, perils, results.' In M Zurn, A Nollkaemper and Randall Peerenboom (eds), Rules of Law Dynamics: in an era of international and transnational governance. New York: Cambridge University Press, pp. 21-47.

Mellado, N B. 2013. 'Regionalismo Sudamericano: Sus Características.' Revista de la Secretaría del Tribunal Permanente de Revisión 1 (1): 137-159.

Meyer, P J. 2019. 'Strategy for Engagement in Central America: An Overview.' Washington, DC: Congressional Research Service.

Morlino, L. 2015. 'Qualidades da democracia: como analisá-las.' Sociedade e Cultura 18 (2): 177-194.

Muggah, R and I Szabo. 2014. 'Changes in the Neighborhood: reviewing citizen security cooperation in Latin America.' Strategic paper 7. Igarapé Institute.

Muggah, R and K A Tóbon. 2019. 'Citizen Security in Latin America: facts and figures.' Strategic paper 33. Igarapé Institute.

Nery, T. 2016. 'UNASUR: a dimensão política do novo regionalismo sul-americano.' Caderno CRH 29 (3): 59-75.

Nolte, D. 2014. 'Latin America's New Regional Architecture: A Cooperative or Segmented Regional Governance Complex?' SSRN Electronic Journal (89).

Nolte, D and L Wehner. 2012. 'UNASUR and the New Geopolitics of South America.' Paper delivered at XXIII World Congress of Political Science. Madrid, 8-12 July.

O’Donnell, G. 2001. 'Illusions about Consolidation.' In M F Plattner and L Diamond (eds), The Global Divergence of Democracies. Baltimore and London: The Johns Hopkins University Press, pp.113-130.

Organization for Security and Co-operation in Europe (OSCE). 2010. ODIHR and Democratic Governance. At https://www.osce.org/odihr/104416?download=true [Accessed on 22 February 2019].

Peralta, G A. 2016. 'El regionalismo centroamericano: entre la unión y la integración.' Oasis 24: 89-105. 
Pozo, P C. 2016. 'Módulo 1: Los Fundamentos de la Integración Regional en Centroamérica.' In Secretaria Geral del Sistema de Integración Centro-Americano (ed), Introducción a la Integración Centroamericana. San Salvador: SICA, pp.1-68.

Pridham, G F M. 1997. 'The international dimension of democratisation: theory, practice and inter-regional comparison.' In G F M Pridham, E Herring and G Sanford (eds), Building democracy? The international dimension of democratisation in eastern Europe. Leicester: Leicester University Press, pp. 7-31.

Priers, K M. 2017. Contested concepts and practices in security governance: evolving security approaches in El Salvador. Ph.D. Thesis, University of Glasgow, UK.

Ramirez, W O. 2016. Integración Centroamericana y seguridad democrática: Estructura Institucional y Estrategias de Seguridad en el Marco del Sistema de Integración Centroamericana. San Salvador: SG-SICA.

Ruvalcaba, D E M and A R Valencia. 2012. 'Construcción de la Unión de Naciones SuramericanasUNASUR.' YUYAYKUSUN 5: 31-64.

Schedler, A. 2001. 'What Is Democratic Consolidation?' In M F Plattner and L Diamond (eds), The Global Divergence of Democracies. Baltimore and London: The Johns Hopkins University Press, pp.149-165.

Segura, L D and D M Romero. 2010. 'Evolución institucional de la seguridad en el marco del sistema de la integración centroamericana 1995-2009.' CRIES: Buenos Aires.

2013. 'Seguridad: perspectivas teóricas y su evolución reciente.' Revista Relaciones Internacionales (86): 99-116.

Sistema de la Integración Centromaericano (SICA). 1991. Protocolo de Tegucigalpa. Tegucigalpa.

1994. Declaración de Guácimo. Managua.

1995. Tratado Marco de Segurança Democrática. San Pedro Sula.

Sistema de Información de la Cooperación Regional (SICOR). 2018. Proyectos Regionales con Gestión financeira. At http://www.sica.int/sica/sicor/ [Accessed on 11 December 2019].

Secretaria General del Sistema de Integración Centroamericano (SG-SICA). 2012. IV Diálogo SICA sobre Integración Regional Plan de Acción en Seguridad Regional. San Salvador.

. 2017. Informe del V Ejercicio de Rendición de Cuentas de la Cooperación Regional del SICA 2017. Merliot.

Summit Meeting of the South American Presidents. 2000. Comunicado de Brasilia. At http://www. iirsa.org/admin_iirsa_web/Uploads/Documents/comunicado_brasilia_esp.pdf [Accessed on 25 February 2019].

Tavares, R. 2014. 'Security in South America: The Role of States and Regional Organizations.' Choice Reviews Online 52 (4): 2243-2252.

Tickner, A B. 2016. 'Securitization and the limits of democratic security'. In D R Mares, A M Kacowicz (eds), Routledge Handbook of Latin American Security. London: Routledge, pp. 67-77.

Tickner, A and M Herz. 2012. 'No place for theory? Security studies in Latin America.' In A B Tickner and D Blaney (eds), Thinking International Relations Differently. New York: Routledge, pp. 92-114.

United Nation Program for Development (UNPD). 1994. Human Development Report 1994. New York: Oxford University Press. 
Union of South American Nations (UNASUR). 2008. Tratado Constitutivo de la Unión de Naciones Suramericanas. Quito.

Vennesson, P. 2008. 'Case studies and process tracing: theories and practices.' In D Della Porta and M Keating (eds), Approaches and Methodologies in the Social Sciences. A Pluralist Perspective. Cambridge: Cambridge University Press, pp. 223-239.

Weiffen, B and R D Villa. 2017. 'Re-Thinking Latin American Regional Security: The Impact of Power and Politics.' In M A G Suarez, B Weiffen and R D Villa (eds), Power Dynamics and Regional Security in Latin America. London: Palgrave Macmillan, pp. 1-23.

The Word Bank. 2019. World Development Indicators | DataBank. At https://databank.worldbank. org $/$ data/reports.aspx?source $=2 \&$ series $=$ VC.IHR.PSRC.P5\&country $=[$ Accessed on 11 December 2019].

\section{Interviews}

Ambassador of Uruguay. 2018. E-mail interview by author. 6 October.

Ambassador of Colombia. 2018. E-mail interview by author. 27 November.

Former Researcher from Instituto de Estudos Estratégicos e Políticas Públicas of Nicarágua. 2018. E-mail interview by author. 4 June.

Official from the Organization of American States in Honduras. 2018. E-mail interview by author. 6 August.

Official from SICA Observatory. 2018. E-mail interview by author. 7 August.

Official of the Ministry of Foreign Affairs of El Salvador. 2018. E-mail interview by author. 7 June.

Official of the Ministry of Foreign Affairs of Brazil. 2018. E-mail interview by author. 26 November.

Official from UNASUR. 2018. Phone interview by author. 30 October.

Representatives of the Programa Estado de la Nación. 2018. E-mail interview by author. 17 May.

Senior Official from the Central American Court of Justice. 2018. E-mail interview by author. 22 May.

Senior Official of the Inter-American Drug Abuse Control Commission. 2018. E-mail interview by author. 6 December.

Senior Official from Peru. 2018. Phone interview by author. 5 October.

Senior Official of the Ministry of Foreign Affairs of Guatemala. 2018. E-mail interview by author.

Senior Official of the Ministry of Foreign Affairs of Guatemala. 2019. E-mail interview by author. 18 February.

Senior Official from the Ministry of Justice and Human Rights of Peru. 2018. E-mail interview by author. 30 October. 


\title{
About the author
}

Octávio Forti Neto is Professor at Centro Universitário do Vale do Ribeira (University Center of Vale do Ribeira - UNIVR), with a Ph.D. from the University of São Paulo (USP) and Master's in political science at University of Campinas (UNICAMP). He serves as Director of Economic Development, Science, Technology and Innovation for the City of Registro, São Paulo. His research is concentrated on regional integration, democracy, rule of law, citizen security and regional organisation. He worked as a research assistant in the project 'The EU, Regional Conflicts and the Promotion of Regional Cooperation: A Successful Strategy for a Global Challenge?'

\section{A Relação entre Organizações Regionais, Consolidação da Democracia e Segurança Cidadã: Os Casos do SICA e da UNASUL}

\begin{abstract}
Resumo: As Organizações Regionais da América Latina (ORs) trabalham ativamente na segurança dos cidadãos há pelo menos 20 anos. No entanto, existe uma relação importante entre a segurança cidadã e a consolidação democrática dos documentos de ORs nessa região, o que nos leva à principal pergunta: 'Qual tem sido o papel das ORs com um nível formalizado de cooperação em segurança cidadã na consolidação democrática?' Para responder a essa pergunta, esta pesquisa baseou-se em dois estudos de caso: O Sistema de Integração Centro-Americano (SICA) e a União das Nações Sul-Americanas (UNASUL) entre 2008 e 2018, período no qual ambas as organizações tiveram ações na área de segurança cidadã. Além disso, a metodologia utilizada nesta pesquisa foi o rastreamento de processos e o rastreamento comparativo de processos. Os resultados desta pesquisa destacam que as organizações desenvolveram uma visão de como ações cooperativas em segurança cidadã podem promover a consolidação da democracia, fortalecendo o Estado de Direito. No entanto, os atores são céticos quanto à capacidade das ORs de obter sucesso, uma vez que falta interesse político e há déficits de recursos, que são as principais barreiras para alcançar grande sucesso no campo da segurança cidadã e, consequentemente, na consolidação da democracia. Conclui-se que as ORs analisadas produzem muito em termos de documentos, mas pouco fazem para alcançar suas ambições, como reflexo das falhas do próprio regionalismo Latino-Americano.
\end{abstract}

Palavras-chave: cooperação em segurança cidadã; regionalismo; consolidação democrática; SICA; UNASUL.

Received on 9 March 2019, and approved for publication on 7 June 2020. 